\title{
UPAYA PENINGKATAN KEAKTIFAN SISWA MELALUI PEMBELAJARAN BERDASARKAN GAYA BELAJAR DI SMK NEGERI 1 SAPTOSARI
}

\author{
Nugroho Wibowo \\ SMK N 1 Saptosari Gunungkidul \\ Email: asyifahaifa3@gmail.com
}

\begin{abstract}
ABSTRAK
Penelitian ini bertujuan untuk mengetahui peningkatan keaktifan siswa melalui penerapan gaya belajar pada mata pelajaran memelihara baterai di SMK Negeri 1 Saptosari. Penelitian ini merupakan penelitian tindakan kelas, dilaksanakan di kelas X TKR B pada semester genap tahun pelajaran 2014/2015. Jenis tindakan penelitian tindakan kelas ini menggunakan model Kemmis dan Taggart. Data dikumpulkan melalui observasi, angket dan dokumentasi, alat yang digunakan untuk mengumpulkan data penelitian: lembar observasi, angket keaktifan siswa, dan checklist dokumentasi. Data yang diperoleh pada penelitian ini dianalisis menggunakan teknik analisis deskriptif dengan presentase, selain itu juga didasarkan pada refleksi tiap siklus tindakan. Hasil penelitian: 1) Pemanfaatan gaya belajar untuk pembelajaran dilakukan melalui tiga tahapan: pencarian data gaya belajar siswa, pengelompokan siswa, dan pemberian materi sesuai gaya belajar; 2) Pemanfaatan gaya belajar dapat meningkatkan keaktifan siswa berdasarkan lima indikator yaitu: perhatian, kerjasama dan hubungan sosial, mengemukakan pendapat atau ide, pemecahan masalah, dan disiplin.
\end{abstract}

Kata kunci: gaya belajar, keaktifan siswa, pembelajaran

\section{PENDAHULUAN}

Peningkatan mutu pendidikan merupakan suatu hal yang terus berkembang di era globalisasi ini, sekolah sebagai penghasil Sumber Daya Manusia (SDM) memegang peranan penting dalam proses peningkatan tersebut. Setiap sekolah dituntut untuk terus meningkatkan mutu pendidikan agar lulusannya unggul dan dapat bersaing dengan lulusan Sekolah Menengah Kejuruan (SMK) yang lain. Sekolah yang unggul dilihat dari beberapa aspek, dua diantaranya adalah aspek akademis dan aspek non akademik. Aspek akademik dilihat dari beberapa indikator yaitu nilai yang diperoleh peserta didik ketika belajar disekolah, nilai-nilai tersebut dipengaruhi oleh prestasi, semakin tinggi nilainya maka prestasi peserta didik tersebut semakin baik pula.

Peserta didik selalu menginginkan peningkatan prestasi dalam pendidikannya, prestasi belajar ditentukan oleh proses belajar, semakin siswa senang belajar maka kemungkinan prestasinya juga baik. Gaya belajar adalah kunci untuk mengembangkan kinerja dalam pekerjaan, di sekolah, dan dalam situasi-situasi antar pribadi. Ketika seseorang menyadari bahwa bagaimana menyerap dan mengolah informasi, belajar dan berkomunikasi menjadi sesuatu yang mudah dan menyenangkan. Secara umum dapat disimpulkan bahwa gaya belajar yang sesuai dengan keinginan peserta didik akan membuat peserta didik mudah memahami materi yang diajarkan, dan akhirnya berdampak positif terhadap prestasi.

Proses pembelajaran yang baik ditentukan oleh beberapa faktor, faktor-faktor tersebut dikelola oleh sekolah melalui sebuah manajemen pendidikan. Manajemen pendidikan digunakan untuk mengelola unsur-unsur didalamnya, Sumber Daya Manusia (SDM), proses pembelajaran, dan sarana prasarana merupakan unsur-unsur penting manajemen pendidikan selain kurikulum, dana, informasi dan lingkungan kondusif. (Mulyasa, 2004:1323).

Menurut Haryanto

di http://belajarpsikologi.com menyebutkan bahwa terdapat enam hal yang mempengaruhi keaktifan sisa dikelas yaitu: siswa, guru, materi, 
tempat, waktu, dan fasilitas. Peran guru dibutuhkan dalam proses aktifitas di sebuah kelas, karena guru merupakan penanggung jawab semua bentuk kegiatan pembelajaran dikelas, aktifitas dikelas bisa diskenario guru sesuai dengan tujuan pembelajaran yang diinginkan. Keaktifan siswa mebuat pembelajaran berjalan sesuai dengan perencanaan pembelajaran yang sudah disusun oleh guru, bentuk aktifitas siswa dapat berbentuk aktifitas pada dirinya sendiri atau aktifitas dalam suatu kelompok.

Partisipasi aktif siswa sangat berpengaruh pada proses perkembangan berpikir, emosi, dan sosial. Beberapa upaya yang dapat dilakukan guru dalam mengembangkan keaktifan belajar siswa dalam mata pelajaran dengan meningkatkan minat siswa, membangkitkan motivasi siswa, serta menggunakan media dalam pembelajaran. Keterlibatan siswa dalam belajar, membuat anak secara aktif terlibat dalam proses pembelajaran. Beberapa pengalaman peneliti dalam proses Penilaian Kinerja Guru (PKG) menunjukkan bahwa pembelajaran saat ini pun masih ada yang menggunakan metode belajar dimana siswa menjadi pasif seperti pemberian tugas, dan guru mengajar dengan metode ceramah, sehingga cenderung membosankan dan menghambat perkembangan aktivitas siswa.

Ciri pengajaran yang berhasil salah satu diantaranya dilihat dari kadar kegiatan belajar siswa. Makin tinggi kegiatan belajar siswa, makin tinggi peluang berhasilnya pengajaran (Nana Sudjana, 2004:72). Menurut Eko Widiyanto (2015) yang meneliti tentang Pengaruh Aktifitas, Kreatifitas dan Motivasi Belajar Siswa terhadap Prestasi Belajar Kompetensi Alat Ukur di SMK Institut Kotoarjo menyebutkan bahwa terdapat pengaruh dari aktifitas belajar siswa terhadap prestasi belajar siswa, hal di atas menunjukkan bahwa aktifitas siswa memegang peranan penting dalam sebuah pembelajaran di kelas.

Dari uraian di atas dapat disimpulkan bahwa terdapat beberapa hal yang mempengaruhi proses pembelajaran di kelas yaitu guru, keaktifan siswa, sarana dan prasarana, metode dan media pembelajaran, aktifitas siswa dapat berupa aktifitas pribadi maupun kelompok, hal di atas menjadi latar belakang peneliti untuk mengetahui bagaimana cara meningkatkan aktifitas siswa dalam pembelajaran di kelas.

Prestasi belajar dapat dipengaruhi oleh proses pembelajaran disekolah, proses tersebut dipengaruhi oleh keaktifan siswa. Proses pembelajaran disekolah masih ditemukan beberapa masalah yang pada akhirnya akan mempengaruhi prestasi belajar, masalahmasalah tersebut diantaranya:

1. Guru belum memaksimalkan proses pembelajaran atau dengan kata lain guru masih menggunakan model pembelajaran yang belum bervariasi sehingga menimbulkan kejenuhan bagi siswa.

2. Kurangnya sarana prasarana pembelajaran praktik yang mengakibatkan guru hanya mengajarkan materi sesuai dengan keadaan sarana prasarana yang terdapat di sekolah tersebut.

3. Aktifitas siswa merupakan salah satu unsur keberhasilan pembelajaran di kelas, aktifitas tersebut meliputi aktifitas secara pribadi maupun aktifitas dalam satu kelompok.

4. Dari observasi peneliti menunjukkan bahwa tingkat keaktifan siswa masih rendah dibuktikan dengan data observasi awal bahwa siswa cenderung pasif dalam aktifitas diskusi kelompok.

Dari uraian di atas dapat ditarik rumusan masalah yaitu:

1. Bagaimana proses pelaksanaan pembelajaran dengan memanfaatkan pembelajaran berdasarkan gaya belajar pada kompetensi dasar merawat baterai di kelas X TKR B SMK N 1 Saptosari?

2. Apakah dengan pelaksanaan pembelajaran dengan memanfaatkan pembelajaran berdasarkan gaya belajar dapat meningkatkan keaktifan siswa dalam proses pembelajaran pada kompetensi dasar 
merawat baterai di kelas X TKR B SMK N 1 Saptosari?

\section{Keaktifan Siswa}

Proses pembelajaran pada hakekatnya merupakan proses interaksi antara guru dengan siswa yang didalamnya berisi aktivitas peserta didik melalui berbagai interaksi dan pengalaman belajar yang dialami oleh keduanya. Keaktifan belajar siswa merupakan salah satu unsur dasar yang penting bagi keberhasilan proses pembelajaran. Dalam Kamus Besar Bahasa Indonesia aktif berarti giat dalam bekerja atau berusaha. Kegiatan bekerja dan berusaha dilakukan oleh siswa dalam proses pembelajaran sesuai dengan materi pelajaran yang disampaikan oleh guru. Keaktifan adalah kegiatan yang bersifat fisik maupun mental, yaitu berbuat dan berfikir sebagai suatu rangkaian yang tidak dapat dipisahkan (Sardiman, 2001:98). Macam aktifitas siswa dalam proses pembelajaran terbagi menjadi dua bagian, bagian pertama adalah aktifitas fisik dan yang kedua adalah aktifitas psikis.

Aktifitas fisik adalah gerakan yang dilakukan siswa melalui gerakan anggota badan, gerakan membuat sesuatu, bermain maupun bekerja yang dilakukan oleh siswa di dalam kelas. Siswa sedang melakukan aktifitas psikis jika daya jiwanya bekerja sebanyakbanyaknya atau banyak berfungsi dalam rangka pembelajaran. Pentingnya keaktifan siswa dalam pembelajaran menurut Mulyasa (2002:32), pembelajaran dikatakan berhasil dan berkualitas apabila seluruhnya atau setidaktidaknya sebagian besar peserta didik terlibat secara aktif, baik fisik, mental maupun sosial dalam proses pembelajaran. Oemar Hamalik (2002:27), menyatakan bahwa dalam proses pendidikan di sekolah, tugas utama guru adalah mengajar sedangkan tugas utama setiap siswa adalah belajar. Belajar merupakan suatu proses, suatu kegiatan, dan bukan suatu hasil atau tujuan. Menurut Sardiman (2001:47), belajar mengacu pada kegiatan siswa dan mengajar mengacu pada kegiatan guru. Mengajar pada dasarnya merupakan suatu usaha untuk menciptakan kondisi atau sistem lingkungan yang mendukung dan memungkinkan untuk berlangsungnya proses pembelajaran.

Dapat disimpulkan bahwa keaktifan siswa dalam belajar merupakan segala kegiatan yang bersifat fisik maupun non fisik siswa dalam proses kegiatan belajar mengajar yang optimal sehingga dapat menciptakan suasana kelas menjadi kondusif.

Salah satu penilaian proses pembelajaran adalah melihat sejauh mana keaktifan siswa dalam mengikuti proses belajar mengajar. Nana Sudjana (2004: 61) menyatakan keaktifan siswa dapat dilihat dalam hal: (1) turut serta dalam melaksanakan tugas belajarnya; (2) terlibat dalam pemecahan masalah; (3) Bertanya kepada siswa lain atau guru apabila tidak memahami persoalan yang dihadapinya; (4) Berusaha mencari berbagai informasi yang diperlukan untuk pemecahan masalah;(5) Melaksanakan diskusi kelompok sesuai dengan petunjuk guru;(6) Menilai kemampuan dirinya dan hasil- hasil yang diperolehnya; (7) Melatih diri dalam memecahkan soal atau masalah yang sejenis; (8) Kesempatan menggunakan atau menerapkan apa yang diperoleh dalam menyelesaikan tugas atau persoalan yang dihadapinya. Berdasarkan uraian di atas dapat disimpulkan keaktifan siswa dapat dilihat dari berbagai hal seperti memperhatikan (visual activities), mendengarkan, berdiskusi, kesiapan siswa,bertanya, keberanian siswa, mendengarkan,memecahkan soal (mental activities).

\section{Faktor-faktor yang Mempengaruhi}

\section{Keaktifan}

Keaktifan peserta didik dalam proses pembelajaran dapat merangsang dan mengembangkan bakat yang dimilikinya, peserta didik juga dapat berlatih untuk berfikir kritis, dan dapat memecahkan permasalahanpermasalahan dalam proses pembelajaran. Dalam upaya peningkatan keaktifan siswa guru dapat berperan dengan merekayasa sistem pembelajaran secara sistematis, sehingga 
merangsang keaktifan peserta didik dalam proses pembelajaran. Kegiatan-kegiatan guru yang dapat mempengaruhi keaktifan siswa menurut Moh. Uzer Usman (2009:26-27) adalah: 1) Memberikan motivasi atau menarik perhatian peserta didik, sehingga mereka berperan aktif dalam kegiatan pembelajaran; 2) Menjelaskan tujuan instruksional (kemampuan dasar kepada peserta didik); 3) Mengingatkan kompetensi belajar kepada peserta didik; 4) Memberikan stimulus (masalah, topik, dan konsep yang akan dipelajari); 5) Memberikan petunjuk kepada peserta didik cara mempelajari; 6) Memunculkan aktifitas, partisipasi peserta didik dalam kegiatan pembelajaran, 7) Memberikan umpan balik (feedback); 8) Melakukan tagihan-tagihan kepada peserta didik berupa tes sehingga kemampuan peserta didik selalu terpantau dan terukur; 9) Menyimpulkan setiap materi yang disampaikan diakhir pembelajaran. Keaktifan dapat ditingkatkan dan diperbaiki dalam keterlibatan siswa pada saat belajar.

Lebih lanjut dijelaskan oleh Moh. Uzer Usman (2009:26-27) cara untuk memperbaiki keterlibatan siswa diantaranya yaitu abadikan waktu yang lebih banyak untuk kegiatan belajar mengajar, tingkatkan partisipasi siswa secara efektif dalam kegiatan belajar mengajar, serta berikanlah pengajaran yang jelas dan tepat sesuai dengan tujuan mengajar yang akan dicapai. Selain memperbaiki keterliban siswa juga dijelaskan cara meningkatkan keterlibatan siswa atau keaktifan siswa dalam belajar. Cara meningkatkan keterlibatan atau keaktifan siswa dalam belajar adalah mengenali dan membantu anak-anak yang kurang terlibat dan menyelidiki penyebabnya dan usaha apa yang bisa dilakukan untuk meningkatkan keaktifan siswa, sesuaikan pengajaran dengan kebutuhankebutuhan individual siswa. Hal ini sangat penting untuk meningkatkan usaha dan keinginan siswa untuk berfikir secara aktif dalam kegiatan belajar.

Berdasarkan penjelasan tersebut maka dapat disimpulkan keaktifan dipengaruhi oleh berbagai macam faktor yaitu membuat pembelajaran menjadi menarik atau memberikan motivasi kepada siswa dan keaktifan juga dapat ditingkatkan, salah satu cara meningkatkan keaktifan yaitu dengan mengenali keadaan siswa yang kurang terlibat dalam proses pembelajaran.

\section{Gaya belajar (learning style)}

Gaya belajar merupakan kecenderungan siswa untuk mengadaptasi strategi tertentu dalam belajarnya sebagai bentuk tanggung jawabnya untuk mendapatkan satu pendekatan belajar yang sesuai dengan tuntutan belajar di kelas/sekolah maupun tuntutan dari mata pelajaran (Slameto,2003). Gaya belajar setiap siswa berbeda, tergantung aspek intern dan ekstern dari siswa tersebut, kecenderungan setiap siswa mempunyai gaya belajar yang lebih menonjol dari gaya belajar yang lain. Dengan adanya pengetahuan tentang gaya belajar setiap siswa akan mengetahui kemampuan mengenal diri yang lebih baik dan mengetahui kebutuhannya. Untuk pihak guru dengan mengetahui gaya belajar tiap siswa maka guru dapat menerapkan teknik dan strategi yang tepat baik dalam pembelajaran maupun dalam pengembangan diri. Seorang siswa juga harus memahami jenis gaya belajarnya. Pengenalan gaya belajar akan memberikan pelayanan yang tepat terhadap apa dan bagaimana sebaiknya disediakan dan dilakukan agar pembelajaran dapat berlangsung optimal.

Fleming dan Mills (1992) dalam Slameto (2003) mengajukan kategori gaya belajar (Learning Style) yang meliputi: VARK (Visual, Auditory, Read-write, Kinestetic). Gaya belajar visual (visual learner) menitikberatkan ketajaman penglihatan, artinya, bukti-bukti konkret harus diperlihatkan terlebih dahulu agar siswa paham. Kecenderungan ini mencakup menggambarkan informasi dalam bentuk peta, diagram, grafik, flow chart dan simbol visual seperti panah, lingkaran, hirarki dan materi lain yang digunakan instruktur untuk mempresentasikan hal-hal yang dapat disampaikan dalam kata-kata. 
Gaya belajar Auditory mengandalkan pendengaran untuk bisa memahami sekaligus mengingatnya. Artinya, untuk bisa mengingat dan memahami informasi tertentu, yang bersangkutan haruslah mendengarnya lebih dulu. Gaya belajar kinestetik mengharuskan individu yang bersangkutan menyentuh sesuatu yang memberikan informasi tertentu agar ia bisa mengingatnya.

\section{METODE PENELITIAN}

\section{Jenis dan Desain Penelitian}

Penelitian ini merupakan Penelitian Tindakan Kelas (PTK) yang dilakukan langsung oleh peneliti dibantu oleh teman sejawat yang ikut mengamati jalannya penelitian.

\section{Waktu Penelitian}

Penelitian dilakukan pada bulan Februari sampai dengan Mei 2015 pada mata pelajaran produktif dengan kompetensi dasar merawat baterai di semester genap tahun pelajaran 2014/2015.

\section{Tempat Penelitian}

Penelitian ini dilaksanakan di kelas $\mathrm{X}$ Teknik Kendaraan Ringan (TKR) B, SMK N 1 Saptosari Gunungkidul dengan alamat Jalan Wonosari - Panggang KM 22, Kepek, Saptosari Gunungkidul, D.I. Yogyakarta.

\section{Subyek Penelitian}

Subyek penelitian ini adalah siswa kelas X TKR B SMK N 1 Saptosari Gunungkidul sejumlah 30 anak, dengan jenis kelamin lakilaki sebanyak 23 orang dan perempuan sebanyak 7 orang.

\section{Jenis Tindakan}

Jenis tindakan penelitian tindakan kelas ini menggunakan model Kemmis dan Taggart. Model ini terdiri dari tiga komponen yaitu: 1) perencanaan, merupakan tindakan yang tersusun dan mengarah pada tindakan, fleksibel dan refleksi; 2) Tindakan dan pengamatan, merupakan tindakan yang dilakukan secara sadar dan terkendali yang merupakan variai praktik yang cermat dan bijaksana, sedangkan pengamatan berfungsi untuk mendokumentasikan pengaruh tindakan bersama progresnya; 3) Refeleki, merupakan suatu kegiatan mengingat dan merenungkan kembali suatu tindakan hasil dari catatan dalam observasi. Penelitian ini direncanakan terdiri atas dua siklus yang diawali dengan tindakan pra siklus, PTK ini terdiri dari perencanaan kegiatan, pelaksanan kegiatan, observasi kegiatan dan adalah merefleksi diri.

\section{Teknik dan Instrumen Pengumpulan Data}

Data lapangan dikumpulkan melalui observasi, angket dan data dokumentasi. Lembar observasi digunakan untuk mencari data tentang proses pelaksanaan model pembelajaran dan tingkat keaktifan siswa pada kegiatan pra siklus dan kegiatan siklus satu maupun dua, lembar observasi diisi oleh guru maupun kolaborator. Metode kuisioner dengan instrumen angket yang berupa pertanyaan maupun pernyataan ditujukan kepada siswa untuk menggali pendapat siswa tentang keaktifanya ketika proses pembelajaran dilaksanakan.

Metode yang ketiga adalah studi dokumentasi, metode ini digunakan peneliti untuk menggali dokumen-dokumen pendukung yang digunakan untuk melengkapi data keaktifan siswa, dokumen yang digunakan adalah buku catatan siswa dan bukti catatan pengumpulan tugas.

Alat yang digunakan untuk mengumpulkan data penelitian adalah lembar observasi, angket pengujian tingkat keaktifan siswa, dan lembar checklist studi dokumentasi. Lembar observasi berisi tentang catatan pengamat yang berupa checklist terbuka dengan 4 alternatif jawaban yaitu: kurang, sedang, baik, dan sangat baik. Instrumen ini berisi lima indikator dengan 11 variabel pengamatan. Untuk instrumen angket terdiri dari 20 pertanyaan atau pernyataan dengan lima alternatif jawaban tentang keaktifan siswa mengikuti proses pembelajaran.

Checklist untuk studi dokumentasi digunakan untuk menggali data tentang 
keaktifan siswa, peneliti menggali data dari dua dokumen yaitu buku catatan siswa dan bukti catatan pengumpulan tugas .

\section{Uji Validitas dan Reliabilitas Instrumen}

Validitas dan reliabilitas instrumen digunakan untuk meneliti apakah instrumen yang digunakan sudah valid dan reliabel. Validitas instrumen dalam penelitian ini dilakukan dengan validitas konstruk. Di mana setelah butir instrumen selesai disusun berdasarkan kisi-kisi instrumen kemudian peneliti mengkonsultasikan dengan Ketua Program Keahlian TKR SMKN 1 Saptosari, kemudian meminta pertimbangan (judgement expert) sebelum dilakukan pengambilan data.

\section{Keabsahan Data}

Setelah data diperoleh kemudian dikumpulkan, dicatat dan diusahakan kebenaranya dengan menggali data yang diperlukan. Triangulasi data digunakan dalam penelitian ini dengan mencari informasi lain untuk memperkaya dan melengkapi informasi serta memunculkan kebenaran data. Triangulasi data yang digunakan dalam penelitian ini adalah dengan triangulasi teknik dimana data keaktifan siswa dicari melalui tiga instrumen yaitu: observasi, angket dan studi dokumentasi.

\section{Analisa Data}

Dalam penelitian tindakan kelas, analisis dilakukan peneliti sejak awal pada setiap aspek kegiatan penelitian. Data yang diperoleh pada penelitian tindakan kelas ini berupa data hasil observasi, hasil angket dan studi dokumentasi yang disajikan dalam bentuk skor nilai atau angka, maka menggunakan teknik analisis deskriptif dengan presentase. Selain itu analisis data pada penelitian ini didasarkan pada refleksi tiap siklus tindakan. Hal ini bermanfaat untuk rencana perbaikan pembelajaran pada siklus berikutnya.

Analisis data dari observasi kegiatan siswa dengan merefleksikan hasil pengamatan berupa keaktifan belajar siswa dianalisis dengan langkah-langkah menghitung perolehan masing-masing dari lima indikator dan membaginya dengan perolehan maksimal.
Adapun rumus data persentase keaktifan belajar siswa adalah sebagai berikut:

$$
P=\frac{f}{N} \times 100 \%
$$

\author{
Dimana : \\ $\mathrm{P}=$ Angka presentase \\ $\mathrm{f}=$ Frekuensi yang sedang dicari \\ persentasenya \\ $\mathrm{N}=$ Number of case (jumlah \\ frekuensi/banyaknya individu) \\ (Anas Sudijono, 2006:43)
}

Pada penelitian ini data angket dianalisis untuk mendeskripsikan atau mengetahui kecenderungan variabel intensitas pengamatan terhadap keaktifan belajar siswa menggunakan skor ideal maksimal dan skor ideal minimal sebagai norma perbandingan empat kategori, yaitu: kategori keaktifan belajar: sangat tinggi, tinggi, rendah dan sangat rendah.

Analisis untuk data dokumentasi menggunakan prosentase, setiap anak dilihat dari dua indikator tugas yang diberikan guru, penskoran dengan cara jika terdapat dokumen diberi skor 1 dan bila tidak ada diberi skor 0 .

\section{Kriteria Keberhasilan}

Kriteria merupakan patokan untuk menentukan keberhasilan suatu kegiatan atau program, dikatakan berhasil apabila mampu mencapai kriteria yang telah ditentukan dan gagal apabila tidak mampu melampaui kriteria yang telah ditentukan. Penelitian tindakan kelas keberhasilannya dapat ditandai dengan pembahasan ke arah perbaikan, baik terkait dengan guru maupun siswa. Keberhasilan suatu penelitian tindakan yaitu dengan membandingkan hasil sebelum diberi tindakan dengan hasil setelah tindakan.

Penelitian ini dimulai dengan pra siklus sampai dengan siklus I dan seterusnya, dan dihentikan ketika telah memenuhi target yang ditetapkan, sebagai acuan untuk mempertimbangkan dan memberikan makna terhadap apa yang telah dicapai sesudah tindakan. Dalam penelitian tindakan kelas ini digunakan kriteria normatif, yaitu dengan 
membandingkan hasil sebelum tindakan dengan sesudah tindakan. Kriteria yang dimaksud adalah apabila keadaan sebuah tindakan menunjukkan siswa keadaan lebih baik dari sebelum tindakan, maka dikatakan bahwa tindakan tersebut berhasil. Adapun kriteria keberhasilan yang digunakan dalam penelitian ini adalah: (1) Terlaksananya pembelajaran pada kompetensi dasar memelihara baterai dengan pemanfaatan gaya belajar sesuai yang direncanakan; (2) Banyaknya siswa yang memperoleh kategori keaktifan belajar siswa adalah $\geq 75 \%$ yang mengacu pada $\mathrm{E}$. Mulyasa (2008:101) bahwa dari segi proses, pembelajaran dikatakan berhasil dan berkualitas apabila seluruhnya atau setidak-tidaknya sebagian besar $(75 \%)$ siswa terlibat secara aktif dalam proses pembelajaran yang dilihat dari lima indikator dalam penelitian ini yaitu: perhatian, kerjasama dan hubungan sosial, mengemukakan pendapat/ide, pemecahan masalah, dan disiplin.

\section{HASIL DAN PEMBAHASAN}

\section{Deskripsi Hasil Penelitian}

\section{Pra Siklus}

Pelaksanaan pembelajaran pra siklus adalah pembelajaran yang berpusat pada guru, dimana guru sebagai pusat informasi, guru menggunakan metode ceramah yang diselingi demonstrasi dan tanya jawab dalam proses pembelajaran. Guru mengamati keaktifan siswa dengan lembar observasi dengan lima indikator keaktifan. Hasil observasi menunjukkan bahwa indikator pertama yaitu perhatian sebesar $62,50 \%$ dari skor maksimal, indikator kerjasama dan hubungan sosial sebesar $37,50 \%$, indikator selanjutnya mengemukakan pendapat atau ide sebesar $50,00 \%$, sedangkan indikator pemecahan masalah sebesar $41,67 \%$ dan indikator terakhir yaitu disiplin sebesar 50,00\% dari skor maksimal.

Data angket yang bersumber dari 30 siswa kelas X TKR B menunjukkan bahwa dari kelima indikator diperoleh skor: indikator pertama sebesar $69,29 \%$ dari skor maksimal, indikator kedua 70,97\%, indikator ketiga sebesar $69,16 \%$, indikator keempat $72,42 \%$ dan indikator kelima sebesar $64,30 \%$ dari skor maksimal.

Dari tiga instrumen keaktifan di atas dapat disimpulkan bahwa keaktifan siswa yang dilihat dari lima indikator yaitu: perhatian, kerjasama dan hubungan sosial, mengemukakan pendapat atau ide, pemecahan masalah, dan disiplin masih rendah hal ini ditunjukkan bahwa keaktifan belum mencapai $\geq 75 \%$ dari skor maksimal atau belum seluruhnya siswa aktif dalam proses pembelajaran.

\section{Siklus I}

Siklus pertama dalam penelitian ini dengan menerapkan pembelajaran berdasarkan gaya belajar siswa, pelaksanaan tindakan dilakukan dalam mengatasi permasalahan tingkat keaktifan siswa yang rendah dengan melaksanakan proses belajar mengajar oleh pelaku tindakan dan dilakukan pengamatan oleh kolaburator atas segala yang terjadi pada saat pelaksanaan tindakan. Siklus pertama ini terdiri dari tiga rangkaian yaitu: perencanaan, tindakan dan pengamatan dan refleksi.

Perlakuan yang dilakukan guru dengan membagi kelompok diskusi berdasarkan tiga gaya belajar, kemudian setiap kelompok diberi perlakuan. Kelompok kinestetik berupa alat dan bahan praktik merawat baterai yaitu pemeriksaan visual dan pemeriksaan berat jenis elektrolit baterai, LKS. Kelompok audio visual berupa film tentang merawat baterai dan LKS. Anggota kelompok visual berupa modul, wall chart, LKS. Setelah siswa melakukan aktifitas masing-masing kemudian berdiskusi dan mengisi lembar kerja siswa, selanjutnya setiap kelompok melakukan presentasi hasil diskusi.

Pengamatan dilakukan untuk mengamati keaktifan siswa berdasarkan lembar observasi. Data observasi pada siklus ini menunjukkan indikator pertama yaitu perhatian sebesar $75,00 \%$ dari skor maksimal, indikator kedua tentang kerjasama dan hubungan sosial sebesar $50 \%$, indikator mengemukakan pendapat atau 
ide sebesar 75,00\%, indikator keempat tentang pemecahan masalah sebesar $58,30 \%$ dan indikator disiplin sebesar $75,00 \%$ dari skor maksimal, jika disajikan pada tabel terlihat:

Tabel 1. Skor keaktifan siswa siklus I berdasarkan instrument observasi

\begin{tabular}{|c|l|c|c|}
\hline No & \multicolumn{1}{|c|}{ Indikator } & $\begin{array}{c}\text { Pra } \\
\text { siklus } \\
(\mathbf{\%})\end{array}$ & $\begin{array}{c}\text { Siklus I } \\
(\mathbf{\%})\end{array}$ \\
\hline 1 & Perhatian & 62.50 & 75.00 \\
\hline 2 & $\begin{array}{l}\text { Kerjasama dan } \\
\text { hubungan sosial }\end{array}$ & 37.50 & 50.00 \\
\hline 3 & $\begin{array}{l}\text { Mengemukakan } \\
\text { pendapat/ide }\end{array}$ & 50.00 & 75.00 \\
\hline 4 & $\begin{array}{l}\text { Pemecahan } \\
\text { masalah }\end{array}$ & 41.67 & 58.33 \\
\hline 5 & Disiplin & 50.00 & 75.00 \\
\hline
\end{tabular}

Sedangkan untuk data angket siswa dapat ditunjukkan pada tabel di bawah:

Tabel 2. Skor keaktifan siswa siklus I berdasarkan instrumen angket

\begin{tabular}{|c|l|c|c|}
\hline No & \multicolumn{1}{|c|}{ Indikator } & $\begin{array}{c}\text { Pra } \\
\text { siklus } \\
(\%)\end{array}$ & $\begin{array}{c}\text { Siklus I } \\
(\%)\end{array}$ \\
\hline 1 & Perhatian & 69.29 & 77.29 \\
\hline 2 & $\begin{array}{l}\text { Kerjasama dan } \\
\text { hubungan sosial }\end{array}$ & 70.97 & 76.56 \\
\hline 3 & $\begin{array}{l}\text { Mengemukakan } \\
\text { pendapat/ide }\end{array}$ & 69.16 & 70.19 \\
\hline 4 & $\begin{array}{l}\text { Pemecahan } \\
\text { masalah }\end{array}$ & 72.42 & 74.68 \\
\hline 5 & Disiplin & 64.30 & 67.96 \\
\hline
\end{tabular}

Sedangkan dari data studi dokumentasi pengumpulan tugas untuk data ketiga keaktifan menunjukkan bahwa sebesar 16 dari 31 siswa atau sebesar 52,6\% mengumpulkan tugas tepat waktu.

\section{Siklus II}

Siklus kedua ini terdiri dari tiga rangkaian yaitu: perencanaan, tindakan dan pengamatan dan refleksi. Berdasarkan data yang diperoleh dari proses kegiatan belajar mengajar pada siklus I, maka dibuatlah perencanaan tindakan dari siklus II sebagai berikut: menyusun deskripsi pembelajaran dengan membuat RPP, job sheet, lembar kerja siswa, modul, menyiapkan film tentang pemeliharaan baterai. Selanjutnya kolaborator melakukan observasi dengan instrumen dan mengisi lembar observasi untuk mencari dan mengumpulkan data selama proses pembelajaran. Refleksi merupakan upaya untuk mengkaji apa yang telah terjadi dan atau tidak terjadi pada saat pelaksanaan tindakan. Hasilnya digunakan untuk menetapkan tindak lanjut penelitian termasuk perubahan tindakan yang mungkin diambil bila siklus sebelumnya belum mampu mengatasi persoalan.

Data hasil observasi pada siklus kedua ditunjukkan pada tabel di bawah ini

Tabel 3. Skor keaktifan siswa siklus II berdasarkan instrumen observasi

\begin{tabular}{|c|l|c|c|c|}
\hline No & \multicolumn{1}{|c|}{ Indikator } & $\begin{array}{c}\text { Pra } \\
\text { siklus } \\
(\mathbf{\%})\end{array}$ & $\begin{array}{c}\text { Siklus I } \\
(\%)\end{array}$ & $\begin{array}{c}\text { Siklus II } \\
(\%)\end{array}$ \\
\hline 1 & Perhatian & 62.50 & 75.00 & 100.00 \\
\hline 2 & $\begin{array}{l}\text { Kerjasama } \\
\text { dan hubungan } \\
\text { sosial }\end{array}$ & 37.50 & 50.00 & 100.00 \\
\hline 3 & $\begin{array}{l}\text { Mengemuka- } \\
\text { kan } \\
\text { pendapat/ide }\end{array}$ & 50.00 & 75.00 & 87.50 \\
\hline 4 & $\begin{array}{l}\text { Pemecahan } \\
\text { masalah }\end{array}$ & 41.67 & 58.33 & 91.67 \\
\hline 5 & Disiplin & 50.00 & 75.00 & 100.00 \\
\hline
\end{tabular}

Data dari lembar observasi menunjukkan bahwa ada tiga indikator yang mempunyai skor maksimum yaitu indikator perhatian, kerjasama dan hubungan sosial dan indikator disiplin. Data pada siklus kedua menunjukkan bahwa lebih dari $75 \%$ siswa teridentifikasi meningkat keaktifannya jika dilihat dari lima indikator keaktifan siswa tersebut di atas.

Sedangkan data angket pada siklus kedua menunjukkan peningkatan dibanding saat pra siklus dan siklus pertama, data selengkapnya ditunjukkan pada tabel di bawah: 
Tabel 4. Skor keaktifan siswa siklus II berdasarkan instrumen angket

\begin{tabular}{|l|l|c|c|c|}
\hline No & Indikator & $\begin{array}{c}\text { Pra } \\
\text { siklus } \\
(\mathbf{\%})\end{array}$ & $\begin{array}{l}\text { Siklus } \\
\text { I (\%) }\end{array}$ & $\begin{array}{l}\text { Siklus } \\
\text { II (\%) }\end{array}$ \\
\hline 1 & Perhatian & 69.29 & 77.29 & 78.06 \\
\hline 2 & $\begin{array}{l}\text { Kerjasama dan } \\
\text { hubungan sosial }\end{array}$ & 70.97 & 76.56 & 77.85 \\
\hline 3 & $\begin{array}{l}\text { Mengemukakan } \\
\text { pendapat/ide }\end{array}$ & 69.16 & 70.19 & 72.90 \\
\hline 4 & $\begin{array}{l}\text { Pemecahan } \\
\text { masalah }\end{array}$ & 72.42 & 74.68 & 75.81 \\
\hline 5 & Disiplin & 64.30 & 67.96 & 70.10 \\
\hline
\end{tabular}

Data studi dokumentasi siswa tentang pengumpulan tugas diperoleh data bahwa sejumlah 31 siswa mengumpulkan tugas yang kedua tepat waktu dengan nilai diatas kriteria ketuntasan maksimal.

\section{Pembahasan Hasil Penelitian}

Pemanfaatan gaya belajar untuk
pembelajaran

Tiga jenis gaya belajar dalam penelitian ini meliputi: Kinestetik (Kinesthetic Learners), Visual (Visual Learner), dan Auditori (Auditory Learners). Gaya belajar visual menitikberatkan pada ketajaman penglihatan, dengan kata lain bukti-bukti konkret harus diperlihatkan terlebih dahulu agar siswa paham. Gaya belajar auditori mengandalkan pendengaran untuk bisa memahami sekaligus mengingatnya, artinya untuk bisa mengingat dan memahami informasi tertentu, yang bersangkutan haruslah mendengarnya lebih dulu. Sedangkan gaya belajar yang ketiga adalah kinestetik, gaya belajar ini mengharuskan individu yang bersangkutan menyentuh sesuatu yang memberikan informasi tertentu agar ia bisa mengingatnya.

Setiap individu siswa dalam proses belajarnya tidak hanya berada pada satu gaya belajar saja tetapi kecenderungannya hanya satu yang menonjol dari ketiganya. Dampak langsung apabila guru memperhatikan tiga gaya belajar pada setiap anak didiknya akan membuat pencapaian materi pada setiap siswa cenderung sama dan berimplikasi pada meningkatkan keaktifan siswa dikelas.
Alur yang digunakan dalam pemanfaatan gaya belajar seperti terlihat pada gambar di bawah ini:

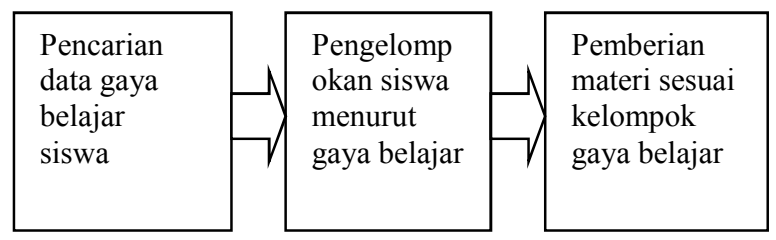

Gambar 1. Alur pemanfaatan gaya belajar untuk peningkatan keaktifan siswa

Ketiga tahapan dalam kegiatan ini dilakukan dalam kelas yang sama yaitu X TKR B SMK N 1 Saptosari Gunungkidul, adapun tahapan-tahapan dapat dilihat pada uraian di bawah ini:

\section{Pencarian data gaya belajar}

Data gaya belajar siswa digali melalui dua instrumen yaitu angket dan wawancara. Instrumen angket untuk mengetahui kecenderungan gaya belajar yang menonjol dari setiap siswa sedangkan instrumen wawancara sebagai data pendukung dari instrumen angket, instrumen angket dan wawancara terlampir pada lampiran. Dari data didapatkan bahwa terdapat 15 siswa bergaya belajar kinestetik, 2 siswa yang audio visual dan 14 siswa visual. Dari data tersebut di atas keudian dibagi kelompok menjadi 3 kelompok kinestetik, 2 kelompok visual dan 1 kelompok audio visual.

\section{Pengelompokan siswa sesuai gaya belajar}

Pengelompokan gaya belajar digunakan untuk dasar pembagian kelompok yang akan digunakan untuk model pembelajaran yang akan dilakukan, artinya pembagian kelompok dapat menyesuaikan dengan kebutuhan model atau metode pembelajaran yang digunakan guru. Apabila akan menggunakan kelompok yang homogen maka pembagian kelompok berdasarkan kelompok gaya belajar tetapi jika ingin menggunakan dasar kelompok yang heterogen maka kita bagi masing-masing kelompok terdapat tiga jenis gaya belajar. Metode yang digunakan penulis dengan 
mengelompokkan siswa sesuai dengan kelompok gaya belajarnya, artinya kelompok kita bagi menjadi tiga kelompok yaitu visual, auditori dan kinestetik karena akan mempermudah dalam penyiapan dokumen dan sarana proses pelaksanaan pembelajaran pada Standar Kompetensi Memelihara Baterai.

\section{Pemberian materi sesuai dengan kelompok}

\section{gaya belajar}

Pemberian materi disesuaikan dengan kelompok gaya belajarnya yaitu: (1) Kelompok kinestetik diberi materi benda langsung berupa baterai, multimeter, hydrometer, batery charger dan lembar kerja siswa (LKS). Guru melakukan demonstrasi cara mememeriksa baterai kemudian setiap anggota kelompok ini melakukan praktik memelihara baterai, sehingga siswa dengan gaya belajar kinestetik menyentuh dan mempraktekkan langsung proses pemeliharaan baterai setelah itu siswa mengisi lembar kerja siswa serta menyiapkan anggota dan materi untuk presentasi. (2) Kelompok audio visual diberi materi tentang film/video tentang memelihara baterai dan LKS, siswa membawa laptop kemudian melihat tayangan video secara bersama dalam satu kelompok kemudian berdiskusi dan menuliskan hasilnya pada lembar kerja siswa. Siswa dalam kelompok ini juga diberi tugas di rumah berdasarkan film/video yang dapat mereka lihat di rumah. (3) Kelompok visual diberi materi rangkuman materi memelihara baterai yang berisi uraian prosedur dan gambar wallchart pemeliharaan baterai, buku manual pemeliharaan baterai. Kegiatan yang dilakukan siswa membaca materi yang diberikan kemudian berdiskusi untuk menjawab pertanyaan yang ada pada lembar kerja siswa, selanjutnya siswa juga mempersiapkan materi dan personil yang bertugas dalam presentasi.

Kejadian yang menarik ketika beberapa siswa yang bergaya belajar audio visual berkomentar "Saya senang pak dengan belajar seperti ini, saya bisa belajar dirumah dengan melihat film/video seperti kesukaan saya mendengarkan mp3 dirumah." Cerita lain juga penulis dapatkan, ketika ada pemahaman yang kurang tentang apa yang tidak bisa dia kerjakan dapat selesai/terklarifikasi ketika presentasi didepan oleh kelompok lain yang bergaya belajar lain. Temuan dari kelompok kinestetik yang berjumlah 3 kelompok terlihat bahwa kelompok ini kecenderungan aktifitas fisiknya banyak, setiap anggota berupaya mempraktikan langsung dan cenderung menjadi saling berebut untuk melakukan praktik, hal ini dapat diantisipasi dengan koordinasi dengan ketua kelompok untuk membagi peran antar anggota kelompok.

\section{Peningkatan keaktifan siswa melalui pemanfaatan gaya belajar}

Data tingkat keaktifan siswa diperoleh dari tiga instrumen, yaitu: lembar observasi, instrumen angket siswa dan studi dokumentasi. Pada siklus pertama dari hasil instrumen lembar observasi diperoleh data pada indikator perhatian terjadi peningkatan sebesar $12,5 \%$ pada siklus pertama dan $25 \%$ pada siklus yang kedua. Pada indikator kerjasama dan hubungan sosial peningkatannya sebesar $12,5 \%$ pada siklus pertama dan $50 \%$ pada siklus yang kedua, sedangkan peningkatan pada indikator ketiga tentang mengemukakan pendapat/ide $25 \%$ dan $12,5 \%$ pada siklus yang kedua. Indikator pemecahan masalah naik sebesar $16,67 \%$ dan $33,3 \%$ pada siklus yang kedua dan indikator terakhir yaitu disiplin naik pada siklus pertama sebesar $25 \%$ dan naik $25 \%$ pada siklus yang kedua, lebih lengkapnya terlihat pada grafik berikut:

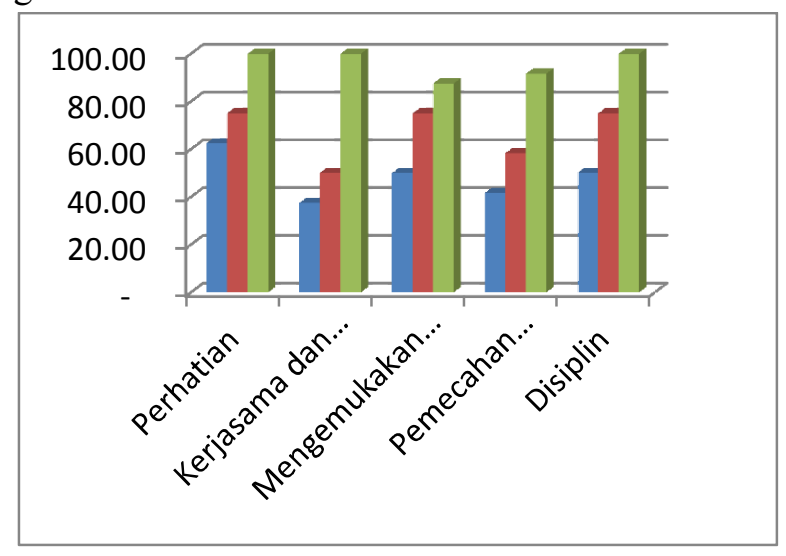


Gambar 2. Grafik data keaktifan siswa berdasarkan instrumen observasi

Dari data di atas dapat disimpulkan bahwa terjadi peningkatan dari kelima indikator keaktifan siswa, peningkatan terbesar dari observasi terjadi pada indikator kerjasama dan hubungan sosial terbukti dengan aktifnya siswa ketika belajar secara kelompok menurut gaya belajarnya sehingga terjadi hubungan yang interaktif atar anggota kelompok.

Data keaktifan siswa yang diperoleh dari instrumen angket siswa diperoleh data peningkatan terbesar pada indikator perhatian sebesar $8,77 \%$ dari pra siklus sampai ke siklus yang kedua. Sedangkan untuk peningkatan terkecil pada indikator pemecahan masalah sebesar 3,39\%, untuk indikator kerjasama dan hubungan sosial meningkat $6,88 \%$, indikator ketiga terjadi peningkatan sebesar $3,34 \%$ dan indikator disiplin sebesar 5,80\%. Lebih lengkapnya seperti pada tabel di bawah:

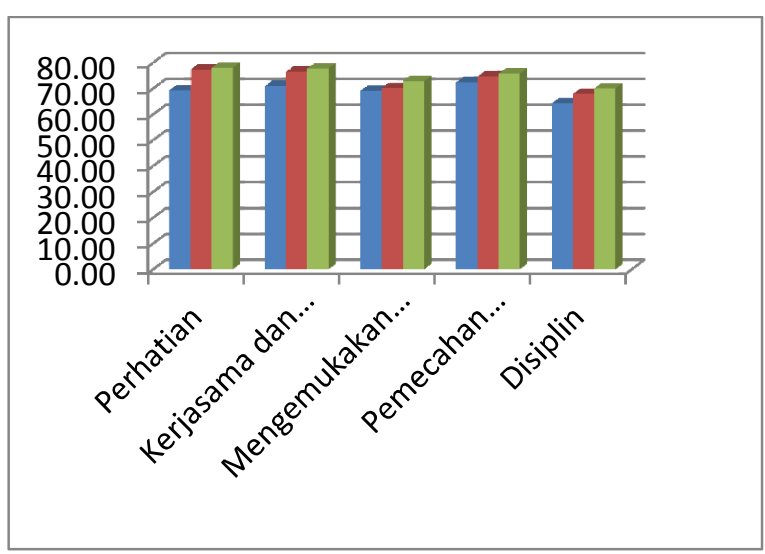

Gambar 3. Grafik data keaktifan siswa berdasarkan instrumen angket

Dari data studi dokumentasi siswa tentang pengumpulan tugas diperoleh data bahwa terdapat peningkatan siswa yang mengumpulkan tugas tepat waktu yaitu dari prosentase $52,6 \%$ pada tugas pertama dan $100 \%$ pada tugas yang kedua.

Dari ketiga instrumen lembar observasi, angket siswa dan studi dokumentasi yang digunakan pada penelitian ini menunjukkan bahwa terdapat peningkatan keaktifan siswa dalam pembelajaran dengan lima indikator yaitu: perhatian, kerjasama dan hubungan sosial, mengemukakan pendapat atau ide, pemecahan masalah, dan disiplin jika dilihat dari hasil pra siklus, siklus pertama dan kedua.

\section{SIMPULAN}

Berdasarkan data hasil penelitian didapatkan kesimpulan bahwa:

1. Pemanfaatan gaya belajar untuk pembelajaran dilakukan melalui tiga tahapan yaitu: a) pencarian data gaya belajar siswa; b) pengelompokan siswa; dan c) pemberian materi sesuai gaya belajar.

2. Pemanfaatan gaya belajar dapat meningkatkan keaktifan siswa berdasarkan lima indikator yaitu: perhatian, kerjasama dan hubungan sosial, mengemukakan pendapat atau ide, pemecahan masalah, dan disiplin.

3. Berdasarkan data angket peningkatan terbesar pada indikator perhatian sebesar $8,77 \%$ dari pra siklus sampai ke siklus yang kedua, sedangkan peningkatan terkecil pada indikator pemecahan masalah sebesar $3,39 \%$.

\section{DAFTAR PUSTAKA}

Anas Sudijono, (2006). Pengantar Evaluasi Pendidikan, Jakarta: Rajawali Press

Eko Widiyanto. (2015) Pengaruh Aktifitas, Kreatifitas dan Motivasi Belajar Siswa terhadap Prestasi Belajar Kompetensi Alat Ukur di SMK Institut Kotoarjo. Jurnal Pendidikan Teknik Otomotif Universitas Muhammadiyah Purworejo. Purworejo

Haryanto. (2012). Keterlibatan Siswa dalam Proses Belajar Mengajar. Artikel. Diambil tanggal 12 Februari 2015, dari http://belajarpsikologi.com

Mulyasa. (2002).Manajemen Berbasis Sekolah: Konsep, Strategi dan Implementasi. Bandung: Remaja Rosda Karya

Mulyasa. (2004). Menjadi Guru Profesional Menciptakan Pelajaran Kreatif dan 
Menyenangkan. Bandung: Remaja Rosda Karya

Nana Sudjana. (2004). Dasar-Dasar Proses Belajar Mengajar. Bandung: Sinar Baru Algessindo

Oemar, Hamalik. (2002). Psikologi Belajar Mengajar. Bandung: Sinar Baru Algessindo

Sardiman. (2001). Interaksi dan Motivasi belajar Mengajar. Jakarta: Raja Grafindo Persada

Slameto. (2003). Belajar dan Faktor-Faktor Yang Mempengaruhinya. Jakarta: Rineka Cipta

Usman, Uzer.(1993). Upaya Optimalisasi Kegiatan Belajar Mengajar. PT. Remaja Rosdakarya: Bandung 